\title{
Financialization in the workplace: Hegemonic narratives, performative interventions and the angry knowledge worker
}

\author{
Jean Cushen* \\ Business School, Dublin City University, Dublin 9, Ireland
}

\begin{abstract}
A B S T R A C T
This paper uncovers how the pressures of financialization were passed from top management to employees and achieved performative hegemony in a subsidiary of a knowledge intensive, high technology, multinational corporation. Qualitative insights from subsidiary directors, management and knowledge workers are presented. The paper demonstrates that financialization is a performative phenomenon which elevates the role of accounting in organizations. It highlights how budgets can serve as a performative mechanism through which top management can narrate a desired reality and pass down a myriad of performative interventions to achieve this reality. The paper uncovers how financialization can cause insecurity, work intensification, suppression of voice and the enactment of falsely optimistic behaviours; all of which prompt distress and anger amongst knowledge workers. The paper also uncovers sources of counter performativity and resistance but demonstrates that employees ultimately participate in their subordination. Employees pursue financialized performative interventions as they interpret them as the primary method of securing their role in a pervasively insecure work environment.
\end{abstract}

(c) 2013 Elsevier Ltd. All rights reserved.

'His boss turned his back, at the same time saying four words, take care of yourself, that was what he said in a tone that was at once deferential and imperative, only the best bosses can combine contrary feelings in such a harmonious way' (José Saramago, All the Names, Harcourt, 2000, p. 107).

\section{Introduction}

Saramago's quote above elegantly illuminates the point long made by critical theorists that workplaces are sites of multiple, contrary interests and narratives which are not easily reconciled. This paper documents how financial interests and narratives can achieve performative hegemony within the knowledge workplace.

\footnotetext{
* Tel.: +353 (0) 1700 8447; fax: +353 (0) 17005446.

E-mail address: jean.cushen@dcu.ie

URL: http://www4.dcu.ie/dcubs/index.shtml
}

Financialization refers to the increasingly significant role of financial markets, financial actors, and financial motives in daily life (Epstein, 2005: 3; Lapavitsas, 2011). Organizations operating within financialized capitalism interact with financial markets to secure capital from removed, financially motivated investors. Early proponents of financialization posited that prioritizing investor returns prompts top management to engage in productive activities that result in business success; i.e. what is good for the investor is good for all (Welch, 1981). Critics later argued that financialization is a less stable, more carnivorous type of capitalism, in part because product markets cannot deliver the immediate and continuous growth required by financial actors (Andersson, Haslam, Tsitsianis, \& Lee, 2008; Foster, 2007; Williams, 2000). Scholarship on financialization is burgeoning and uncovers compelling aggregate trends relating to the employment relationship. It is widely accepted that this mode of capital accumulation results in losses for labour; causing job and financial insecurity in particular (Batt \& Appelbaum, 2013; Thompson, 2013). However explanations of the relationship between 
financialization at the level of the economy and workplace outcomes remain under-specified. There is also a dearth of accounts from employees meaning scholarship is at best unaware of what employees experience on a daily basis and is at worst encouraging a default view of employees as hapless recipients of deterministic financialized outcomes. This article makes an empirical contribution by documenting how financialization pervaded daily life within the Irish subsidiary of 'Avatar' (pseudonym), a publicly listed, high-technology, knowledge intensive, multinational corporation (MNC). Data is presented from annual reports, financial media, interviews and observations.

In-depth studies of financialization reveal that financial actors seek financial returns from organizations along with compelling strategic narratives which indicate the organization is pursuing formulaic strategies to achieve future returns (Froud, Johal, Leaver, \& Williams, 2006; Zorn, Dobbin, Dierkes, \& Kwok, 2005). This paper argues that financialization within organizations is defined precisely by the stream of performative interventions organizations take to live the narrative, deliver returns and ultimately be a model of shareholder value creation. Consequently, understanding financialization within organizations requires exploring how these interventions are co-ordinated, received, challenged and sustained to achieve a hegemonic influence and be both performative and possibly counter performative. It is these micro level features of financialization that have not received sufficient attention and what this paper explores.

The paper first presents existing scholarship on financialized corporate governance structures and narratives. Secondly, it presents the case organization and details how Avatar top management were experiencing pressures that typify financialization. Thirdly, the paper documents how budgets were the central mechanism used to transfer performative interventions from Group top management to subsidiary directors and then onto lower levels. Fourthly it explores how financial narratives pervaded the knowledge labour process, creating behavioural scripts and categories of knowledge work which rendered employees accountable for their contribution. Finally it discusses the employment outcomes, counter performativity, resistance and the emergence of the angry, insecure knowledge worker.

\section{Financialization, performative accounting and knowledge workers in the literature}

\section{Financialized corporate governance structures}

Scholarship on financialization and workplaces has been dominated by quantitative studies uncovering aggregate trends. The outcomes are typically explained in terms of structurally determined causality, owner-fiduciary views of corporate governance and stakeholders as rational agents of capital. The interests of capital dominate stakeholders to a greater extent in financialized, liberal market economies (LMEs) (Andersson, Lee, Theodosopoulos, Yin, \& Haslam, 2012; Boyer, 2000; Gospel \& Pendleton, 2003).
Publicly listed firms in LMEs seek capital from mobile investors who judge organizations on share price and prospective financial returns (Dobbin, 2005; Zorn et al., 2005). Distinct pressures arise in such organizations as product markets often fail to yield sufficient returns to satiate investor appetites and maintain share price (Foster, 2007). Fear of divestment and hostile takeover, not to mention loss of personal remuneration, has led to increased incidence of top management boosting investor returns by pursuing short-term, financially myopic strategies. Such strategies include taking on debt and limiting internal investment possibly to the detriment of long-term competitiveness (Aglietta \& Breton, 2001; Appelbaum, Batt, \& Clark, 2013; Bezereh \& Goldstein, 2013; Carr \& Tomkins, 1998; Lazonick, 2012). Indeed financial actors tend not to respond positively to complex exploratory innovation (Gupta, 2012). Organizations are also more likely to cut costs, downsize and engage in continuous restructuring (Froud, Haslam, Johal, \& Williams, 2000; Lazonick, 2012; Milberg \& Winkler, 2009; Shin, 2010; Thompson, 2003). Empirically, these accounts uncover compelling trends but do not provide an insight into how financialization is activated in different settings.

In-depth studies reveal the varying ways the logic of financialization can unfold. Commentators from economic geography (Pike \& Pollard, 2010) and cultural economy (Erturk, Froud, Johal, Leaver, \& Williams, 2008: 239; Froud et al., 2006) demonstrate that the activities and outcomes associated with financialization are not uniformly determined at the level of corporate governance. Investors may want different things (Hendry, Sanderson, Barker, \& Roberts, 2006; Ryan \& Schneider, 2003). Across LMEs there are varying approaches to meeting the needs of financial actors (Faulconbridge \& Muzio, 2009; Lutz, 2004). Furthermore, top management do not always act as rational agents of capital; they can take careless risks (Dobbin \& Jung, 2010), exercise discretionary power (Gomez, 2004), retain and reinvest (Froud et al., 2006) and be affected by internal and external relationships (Pye, 2004). This is not to say that financial actors do not create distinct pressures for top management. Financial actors certainly constrain management action by shaping performance expectations and defining which financial metrics matter (Froud et al., 2006:122-136). It simply means that management can interact with financial actors in different ways and take varying approaches to optimize investor returns.

\section{Hegemonic financialized narratives}

An emerging body of qualitative work demonstrates that financialized capitalism is not distinguishable solely because of pressure for high returns; what is also unique is the significant role of narratives (Erturk et al., 2008: 239; Hendry et al., 2006; O’Neill, 2001; Pike \& Pollard, 2010; Roberts, Sanderson, Barker, \& Hendry, 2006; Zorn et al., 2005). For these authors, financial actors such as investors, rating agencies and financial media are not a predictable, deterministic source of discipline. Instead financial actors function as co-authors of ever changing, speculative, unstable economic, industry and company narratives that affect estimations of an organization's 
worth. This makes management of investor relations, in itself, a route to organizational success or failure (Hendry et al., 2006; Roberts et al., 2006; Zorn et al., 2005). Financialization, they claim, is not about management creating value for investors by embracing strategies that have knowable financial outcomes. Instead, management construct optimistic narratives proclaiming the value creation potency of their strategy in order to shape the narratives and subsequent valuation and investment decisions of other financial actors. A study of the relationship between top management and institutional investors shows how 'management set the targets against which they wanted performance to be measured. Those targets were then 'sold' to 'the market' (Hendry et al., 2006: 1117). These narratives represent the promises of management who later concern themselves with ensuring the financial numbers corroborate earlier narratives. However not all product markets are amenable to ever changing narratives and continuous revenue growth. Furthermore cost cutting can have unpredictable negative consequences within organizations. Uncertainty prompts the creation of more narratives as actors seek to edit and simplify the complexity and obstacles that emerge within both the product market and organizations. Therefore the pursuit of investor/shareholder value is not a prescriptive functional strategy with knowable outcomes but a rhetoric that 'sets management on a utopian quest for growth and high returns for capital that has variable and uncertain consequences' (Froud et al., 2006, p. 65).

Whilst the narrative exchange between financial actors and top management is dynamic, financialization is certainly not a narrative 'free for all'. Ultimately financial actors have to be satisfied and the narrative pivots upon the material exchange of financial returns. Analyzing narratives prompts consideration of the forms in which knowledge is cast and the effects that these have on an audience' (Czarniawska, 1997: 6, and within financialization narratives are consistently cast in financial terms to affect a financial audience. Lower level organizational actors are not party to this process meaning they do not have access to the actors constructing the hegemonic narratives shaping their lives. Gramsci defines hegemony as 'The "spontaneous" consent given by the great masses of the population to the general direction imposed on social life by the dominant fundamental group; this consent is "historically" caused by the prestige (and consequent confidence) which the dominant group enjoys because of its position and function in the world of production' (Gramsci, 1971: 12 in Mumby, 1997: 348). However, whilst hegemonic narratives emerge hegemony is not automatic and competing narratives always exist. This requires an understanding of how financialized depictions of reality become hegemonic within organizations and acquire transformative capacities with 'performative potential' (Thompson \& Harley, 2013: 1364).

\section{Performative accounting}

Callon, in his influential works on the performativity of economics, states that exploring performativity involves investigating the extent to which a formula or model, rather than representing reality, directly intervenes to construct the reality it purports to describe (Callon, 1998). Performativity orients attention to the interventions that a depiction of reality prompts making it a particularly valuable analytical lens for understanding financialization in workplaces. Financial actors seek convincing strategic narratives which indicate the organization is a model of shareholder value creation pursuing formulaic strategies which will achieve financialized targets. Financialization in organizations is defined by the stream of interventions organizations take to live the narrative and be a model of shareholder value creation. These narratives and subsequent interventions mean financialization in organizations is precisely a performative phenomenon. To acquire performative capacities narratives require 'calculative agents' who act according to it (Callon, 2007: 323-326). A calculative agent comprises the person and the calculative equipment, such as rules or instructions, endowing them with capacity for acting. Multiple agents deploying calculative equipment to bring about a narrative can be considered to be performative 'mechanisms' as mechanisms are:

‘...an assembly of elements producing an effect not inherent in any one of them. A mechanism is not so much about 'nuts and bolts' as about 'cogs and wheels'...the wheelwork or agency by which an effect is produced' (Hernes 1998, p. 74 in Davis \& Marquis, 2005, p. 336).

The extensive literature exploring how accounting serves as an organizational coordination device highlights the performative capacities of accounting (Ahrens \& Chapman, 2006; Briers \& Chua, 2001; Cooper \& Hopper, 2007; Frow, Marginson, \& Ogden, 2010; Miller \& O'Leary, 2005; Skaerbaek \& Tryggestad, 2010). A handful of case studies uncover how accounting practices can be leveraged to bring financialized narratives to life. Froud et al. (2006) present case studies detailing how organizational strategy has become organized around achievement of priority financialized metrics. However they employ secondary sources and do not explore how the subsequent performative interventions are experienced by lower level actors. O'Neill highlights how the 'portfolio management model' creates hegemonic narratives for top management around free cash flow that prioritizes certain voices within the top management community to 'drive an organizational form and guide management decision-making' (2001, p. 196). However O'Neill's study focuses on top management only. Faulconbridge and Muzio (2009) demonstrate how new financialized narratives and practices, namely 'profits per equity partner' 'reproduced the logic of finance capitalism in the domain of law' (2009, p. 658). However the law firms studied are not publicly listed and there is no clear link to external capital actors or internal lower level actors. Gleadle and Haslam (2010) explore how narratives relating to research and development can be centered on commercial income and deployed to boost firm valuation. However this study does not explore wider consequences on the employment experience. Generally these studies reveal how accounting can endow top management with the material practices to render a financial narrative hegemonic; yet they shed no insight into how the narratives 
are experienced and sustained by lower levels. This is problematic because hegemony is not automatic and performative does not mean prophetic. Inherent in the concept of performativity is the possibility of 'counterperformativity' (MacKenzie, 2007) whereby the performative mechanism produces unexpected outcomes which may undermine it. The literature exploring the relationship between financialization and employment outcomes identifies outcomes that can be considered counter performative.

\section{The knowledge worker}

It is widely accepted that financialization generates distinct priorities for investors which govern top management decision making and results in losses for labour (Batt \& Appelbaum, 2013; Gospel \& Pendleton, 2003; Thompson, 2003; 2013). Financialized corporate governance structures pull apart and polarize the interests of top management and employees. Continuous cost cutting, restructuring and change means financialization is associated with job insecurity (Kalleberg, 2010; Lazonick, 2012; Shin, 2010), reduced share of national income (Dünhaupt, 2013) offshoring (Milberg \& Winkler, 2009) less secure remuneration and benefits (Jackson, 2005; Langley, 2004), work intensification (Burchell, Ladipo, \& Wilkinson, 2002) and increased hierarchical command (Mintzberg, Simons, \& Basu, 2002; Thompson, 2003). The fragile fusion of long term reciprocity and compromise which powers the employment relationship in more corporatist models of capitalism is unravelling under financialization.

There are a handful of case studies exploring financialization and accounting within organizations. Notable for its inclusion of the employee perspective is the study of 'Conglom' where hegemonic financialized narratives and accounting metrics served to 'inculcate in staff a culture of making the numbers' (Ezzamel, Wilmott, \& Worthington, 2008: 110). Shopfloor production operators in 'Conglom' cynically questioned the legitimacy of the hegemonic financialized discourse but came to a mutual accommodation based largely on favourable terms and conditions. Alvehus and Spicer (2012) claim that billable hours in professional service firms function as a financialized form of control. However the study looks at billable hours in isolation and makes no link to financialized corporate governance or narratives. Gleadle and Cornelius (2008) explore how the economic value added model served as a control device through which financialized targets and changes to work practices where achieved in 'Midco'; amidst economic insecurity. However, this study focuses primarily on management with the employee voice articulated solely through one shop steward. Collectively these studies highlight how accounting practices are implicated in organizational control; a point long argued by critical accounting scholars (see Cooper \& Hopper, 2007 for a review). However the employee voice remains largely absent within scholarship on financialization. This is problematic not solely because of the empirical void but also because what is known about the relationship between financialization and employment outcomes is fundamen- tally at odds with organization level scholarship exploring knowledge intensive organizations.

This paper studies a knowledge intensive firm (KIF) where 'most of the work is said to be of an intellectual nature and where well-educated, qualified employees form the major part of the work force' (Alvesson, 2001: 863). Literature exploring the management of knowledge workers tends to be 'knowledge based' and does not incorporate capital market pressures and associated tensions into the discussion. Instead knowledge based accounts position the creation and co-ordination of knowledge as the central purpose of the firm (Lam, 2000). Knowledge management literature assumes that knowledge creates products and services which yield profit via the product market; therefore effective knowledge management is depicted as the primary, if not only, source of organizational wealth. KIF's are described as being highly dependent on employees' valuable, tacit knowledge and it is claimed that employees are more likely to deploy tacit knowledge in high-road, secure, lucrative and engaging jobs (Alvesson, 2001). This results in optimistic depictions of knowledge workers as holding so privileged an employment position that they are devoid of material concerns (Drucker, 1996, p. 17). A more sobering view of the knowledge employment relationship has emerged from studies incorporating financial pressures into the analysis. The dismantling of stable employment under financialization can provoke a crisis of attachment for professional workers (Cushen and Thompson, 2013; Kunda \& Ailon-Souday, 2005; McCann, 2013). These studies do not explain how financialization is passed down and mediated to shape knowledge work. Palpacuer, Seignour, and Vercher (2011) claim financialization is associated with a move to 'market-based HRM' for skilled workers in six multinationals in France. However this study does not clearly trace how the financialized strategies of the case organizations translated into HRM outcomes. Furthermore, the findings relating to employees are limited by the sample of interviewees not all of whom worked for the six multinationals and most of whom held management positions. For insights into how accounting can permeate knowledge work we must turn to scholarship on academia. Numerous studies reveal how 'New Public Management' has commodified academic work and encroached on academic autonomy (Cooper \& Hopper, 2007: 225-226; Deem, 2004; Giroux \& Myrsiades, 2001). Increased prominence of financial metrics in higher education has enhanced the insecurity and individualization of academic work (Harney, Monks, Alexopoulos, Buckley, \& Hogan, 2011; Waring, 2013). Whilst universities are not (yet) listed on stock exchanges these studies highlight that knowledge work and workers are not invincible to financial control, insecurity and commodification. However, scholarship has been dominated by the knowledge based approach which misses the crucial point that a defining feature of financialized capitalism is that firms are oriented towards accumulating capital from financial markets more so than product markets.

Ultimately the existing literature uncovers compelling, even startling trends concerning employment outcomes under financialization which indicate the hegemonic force of financialized interests within organizations. Despite these losses most studies do not capture employee 
perspectives or explore how financialization encroaches on knowledge work. There are few insights into the micro level struggles in financialized organizations which are central to Gramsician dialectical notions of hegemony where domination cannot be assumed (Mumby, 1997). Hegemony is never automatic and 'even those in the most subordinate positions can 'carve out spaces of controls in respect of their day-to-day lives' (Mumby, 1987: 117). Existing studies of financialization reveal that narratives and associated returns often do not materialize in the manner predicted prompting continuous interventions as organizations scramble to find alternative routes to the promised future. So understanding working life within a financialized organization requires exploring how a continuous streams of performative interventions are co-ordinated, received, challenged and sustained, amidst uncertainty and insecurity. It is precisely these key features of financialization that have not received sufficient attention and what this paper seeks to explore.

\section{Methods}

Case

This paper presents data from a 6 month, mixed method ethnographic study undertaken in Avatar Ireland from June to November 2007. Avatar is a critical case selected as it exemplifies a financialized, KIF. The parent organization Avatar Group (Group) was established in the mid1980s. Group headquarters are located in a large LME. Categories of Group shares are listed on major stock exchanges in two LMEs. A global corporate governance rating agency 'Governance Metrics International' assigned Avatar an overall rating of ten out of ten. Avatar is a global, market leading provider of a range of high-technology services and products. It is one of the largest organizations in the world and it consistently ranks highly within publications listing the largest, 'most innovative', 'best known brands' and 'great places to work'. The Irish subsidiary was a distinct profit and loss unit tasked with meeting financial targets and delivering a range of products and services to the Irish consumer market. Avatar Ireland had, for a number of years, generated significant profits and had one of the highest product market margins within Avatar Group. In 2007 Avatar Ireland employed approximately 850 full-time, permanent, employees in Ireland. In terms of demographics, seventy-nine percent were under forty; approximately sixty percent were male. Most employees held a third level qualification and were engaged in knowledge work and comfortably meet Warhurst and Thompson's (2006) criteria of employees who use a body of theoretical (specialized and abstract) knowledge that is utilized to innovate products and processes.

\section{Data and analysis}

Commentary in financial media and annual reports were analyzed. Company documents relating to the business strategy, work and people management practices were reviewed. Seventy-five semi-structured interviews, totalling approximately one hundred hours, were conducted incorporating eleven directors, twenty-two managers, thirty-nine employees and three relevant external individuals. When presenting data the term 'top management' refers to Avatar Groups' top management team, 'directors' refers to the top management team within Avatar Ireland, it does not refer to the Avatar board of directors, 'senior management' refers to the managers of Avatar Ireland who reported directly into a director, 'line managers' refers to middle level managers in the Irish subsidiary who did not report into a director and 'employees' refers to the employees of Avatar Ireland. Avatar Ireland comprised of a large number of distinct roles. The most common role was that of engineer; however the sample includes knowledge workers doing different jobs in all departments including technology, accounting, human resources (HR), marketing, strategy and legal. The breakdown is broadly indicative of the overall organization composition. Twenty-five meetings were attended including management meetings, corporate governance meetings, team meetings, HR management meetings and general communication sessions. This amounted to approximately one hundred hours of attendance at meetings. The data was collated and analyzed using an NVivo tree coding structure. Corporate governance structures and associated financial returns and narratives emerged and these became title-nodes. Subsequent performative mechanisms, interventions and employee outcomes became tiered sub-nodes (see Scheme 1)

\section{Avatar Group}

\section{Financialized narratives and returns}

Avatar Group managed the financial and narrative exchange with external financial actors. Corporate

\begin{tabular}{|l|l|l|}
\hline $\begin{array}{l}\text { Title Nodes: Structures \& } \\
\text { Narratives }\end{array}$ & Sub Nodes: Performative Mechanisms & $\begin{array}{l}\text { Employee Node: Employment } \\
\text { Outcomes }\end{array}$ \\
\hline - Financialized Corporate & - Budgets and Performative Interventions & - Anger \\
Governance Structures & $>$ Return on capital expenditure. & - Categories of work \\
- Company Narratives: & $>$ Reducing operational expenditure & - Change \\
$>$ Revenue Generation & & - Flexibedience \\
$>$ Cost Cutting & & - Insecurity \\
& & - Suppression of voice \\
& & - Work intensification \\
\hline
\end{tabular}


documentation stated Group was responsible for 'The overall financial performance of the Group in fulfilment of strategy, plans and budgets and Group capital structure and funding'. Group was a centralized, strategic 'thinktank' which directed subsidiaries to realize the financial benefits of the business strategy on behalf of investors. Group's business strategy was to deliver premium price, premium quality, high technology products and services and achieve global economies of scale. They sought to be the market leader in each consumer market they operated, securing the revenue and cost efficiencies that go with such scale.

The year 2003 was a time of strategic change in Avatar. A new Group CEO was appointed in 2003 amidst rising unease that the Avatar share price was underperforming relative to other organizations within the high technology index that Group was listed in. Investors also expressed concern that Avatar's technological direction, once ground-breaking, had reached maturation meaning products market would not yield growing returns. Investors were reluctant to sell Avatar shares for fear Avatar would outperform the index so instead they opted for 'active engagement' (Hendry et al., 2006: 1113). Investors called for the CEO to curb spending, take on debt and make higher returns. They also sought evidence of technological innovation that would yield future growth in returns. The financial performance and returns made by Avatar Group to investors in the years after the new CEO took office are highlighted in Table 1 . Throughout this period they also took on more debt and engaged in share buybacks, a tactic known to boost share prices by decreasing the pool of available shares which also limits opportunities for internal investment (Lazonick, 2012).

Group sought to shape financial markets perception of their strategy through 'market story-selling' (Froud et al., 2006; Hendry et al., 2006). Projected returns of Avatar market stories were announced before implementation began at subsidiary level. Specifically, Avatar sought to appease financial actors' concerns and boost the share price by announcing market stories about new revenue streams and cost savings. To make clear the projected financial benefits of these strategies they were framed in narratives relating to levels of capital and operational expenditure and associated returns. Capital expenditure (CAPEX) funds development of new products, services, processes and equipment and Group constructed a CAPEX narrative to announce and defend investment in new revenue streams and projected financial returns. Operational expenditure (OPEX) incorporates the ongoing expenses of operating a business and includes employee costs such as salaries,

Table 1

Avatar Group financial performance.

\begin{tabular}{llll}
\hline Financial year & Profit after tax & Earnings per share & Dividend \\
\hline $2003-2004$ & $17 \%$ increase & $34 \%$ increase & $20 \%$ increase \\
$2004-2005$ & $7 \%$ increase & $11 \%$ increase & $100 \%$ increase \\
$2005-2006^{\text {a }}$ & $335 \%$ decrease & $362 \%$ decrease & $50 \%$ increase \\
$2006-2007$ & $76 \%$ increase & $72 \%$ increase & $11 \%$ increase \\
\hline
\end{tabular}

a Due to 'once off write down of the value of acquired capital assets. benefits and training; the higher this expenditure the less cash available to return to investors or reinvest in the business. OPEX provided a narrative for Group to outline cost reductions. This budgetary narrative is known to yield financial benefits. CAPEX announcements are known to generate significant abnormal positive financial returns in the UK (Akbar, Zulfiqar, Shah, \& Saadi, 2008) and the US (Vafeas \& Shenoy, 2005). Financial markets react positively to stories about reductions in OPEX such as redundancy announcements (Farber \& Hallock, 1999). Furthermore, layoff announcements are associated with higher CEO compensation (Shin, 2010). Ultimately, throughout this period Group top management sought to offset investor concerns by investing quickly and heavily in new revenue streams and cutting costs. Indeed some of these market stories prompted a boost in share price. Table 2 contains an overview of the market stories launched by Group.

Group continuously increased the dividend over this 4 year period; nonetheless they faced highly publicized pressure from investors who were unwilling to have their appetite for returns satiated and were sceptical about future growth. This scepticism arose as the optimistic market stories relating to new revenue streams largely failed to yield the promised returns in the product market and progress with cost reductions was deemed slow. The failure of one market story led to the creation of more and the constant change exacerbated speculation that Avatar was unable to develop beyond their primary products and services. The cost of write downs and the lack of significant new revenue streams saw Avatar's share price plummet to a level that caused some to claim Avatar was undervalued and ripe for a hostile takeover. Avatar Group's share price movement during these years is outlined in Fig. 1.

Investor concerns came to a head at the 2006 annual general meeting where protests were staged and a handful of institutional investors, representing 15\% of shareholders, refused to back the re-election of the Group CEO. Investors rejected the executive bonus plan, describing it as 'easy' and 'disgraceful' and claimed the board of Avatar Group were 'dysfunctional' and 'charlatans'. Group subsequently committed to an ongoing dividend pay-out ratio of $60 \%$ of earnings which tied up Avatar's cash for future years. Financial media labelled this a ruinous measure and an indication the CEO was buying time. Ultimately the inability of the product market to yield sufficiently high returns created pressure on top management to pay a high dividend by reducing internal investment and cutting operating costs in order to 'buy time' and prevent share divestment; all the while they sought to develop new revenue streams.

The CAPEX and OPEX budgets served as a narrative tool at the corporate governance level and were therefore key indicators of whether Group were delivering on market stories. Avatar Group annual reports noted the quarterly and annual budgeting process was used to create a robust parent-subsidiary 'control environment'. This was important for Group because of the need first to pass down a continuous stream of interventions and secondly to scrutinize and control subsidiary expenditure and returns. In the year prior to the ethnography the Avatar Ireland CAPEX 
Table 2

Avatar Group market stories.

\begin{tabular}{|c|c|c|}
\hline Financial year & CAPEX & OPEX \\
\hline $2003-2004$ & - New revenue streams via innovation of products and services & $\begin{array}{l}\text { - OPEX reduction } \\
\text { - 'One Avatar' economies of scale and centralization }\end{array}$ \\
\hline $2004-2005$ & $\begin{array}{l}\text { - New revenue streams via innovation of products and services } \\
\text { - CAPEX reduction }\end{array}$ & $\begin{array}{l}\text { - OPEX reduction } \\
\text { - Organization restructuring } \\
\text { - 'One Avatar' }\end{array}$ \\
\hline 2005-2006 & $\begin{array}{l}\text { - New revenue streams via new Group function dedicated to } \\
\text { innovation of products and services } \\
\text { - CAPEX reduction }\end{array}$ & $\begin{array}{l}\text { - OPEX reduction } \\
\text { - Regional organizational restructuring } \\
\text { - 'One Avatar' } \\
\text { - Redundancies } \\
\text { - Outsourcing }\end{array}$ \\
\hline 2006-2007 & $\begin{array}{l}\text { - New revenue streams via significant shift in technological direction } \\
\text { - CAPEX reduction }\end{array}$ & $\begin{array}{l}\text { - Reduction of OPEX } \\
\text { - Re-organization } \\
\text { - 'One Avatar' } \\
\text { - Outsourcing } \\
\text { - Redundancies }\end{array}$ \\
\hline
\end{tabular}

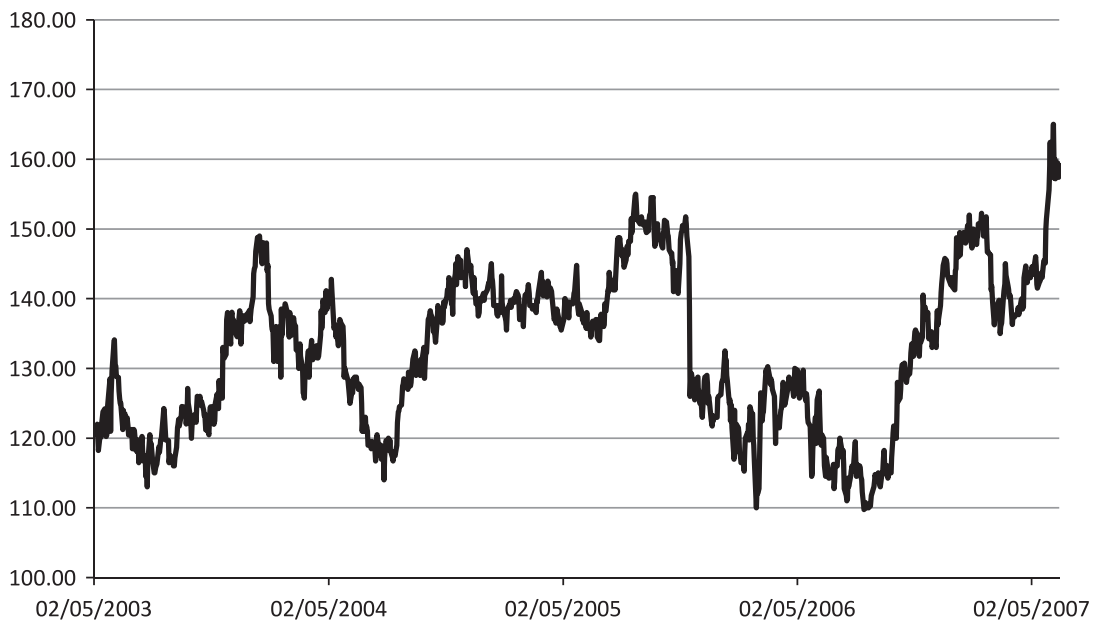

Fig. 1. Avatar Group share price 2003-2007.

and OPEX budgets had both been reduced by ten million euro and were targeted for further reduction. Failure to achieve targets reportedly made it more difficult for Avatar Ireland to secure approval for future budgets and the discussions were likened to a battle. In this way, and as the next section will further illustrate, budgets were a performative mechanism through which market stories were launched and lived out by lower levels via a series of performative interventions.

\section{Budgets as a financialized performative mechanism amongst directors}

Controlling revenue generation via the capital expenditure budget

Group sought to align Avatar Ireland to Group's revenue generation strategy in two ways. First, Group approved subsidiary CAPEX on the basis of alignment with the strategy. Secondly, Group passed down what they termed 'mandated' projects and targets of varying scale and consequence; some of which were unforeseen. Subsidiaries were expected to accept mandated products and services, and associated targets, without question. The continuous stream of seen and unforeseen mandates meant that pursuing revenue generation targets went hand in hand with continuous change and work intensification as one director commented:

There is constant tension there. . The CEO presents the budget and gets agreement from Group and basically that is the most important line of influence. The CEO calls the shots here, however there's lots of help from Group by way of extra products and services or ideas. That's fine if it's factored into the budget, then we've seen it and that's helpful so we embrace it. The areas of dissidence are when something comes along that wasn't in our plan, that we didn't have the resources assigned to...Things do happen that Group needs to do as a whole and you just have to grin and bear it. 
Some unforeseen mandates emanated from failed revenue generation market stories. In such instances Group pursued alternative ways to secure return on CAPEX invested such as identifying new products and services that could be launched from the technological infrastructure developed for the failed market story. Other unforeseen mandates were new ideas which contributed to the achievement of a market story; these ideas came from Group or other subsidiaries. The continuous change created communication tensions as another director commented:

We embarked on certain journeys and routes because Group wanted us to...[...]...on a Group level they decide that "No actually, this isn't the right way". We change direction, and have undermined the trust locally because from one day to another you could find yourself in a situation standing in front of everybody saying "Yes this is definitely what we will do. This is so important!" and then the next week you have to communicate "No actually we're not going to do that, so what I said last week, forget about it".

Furthermore, the lack of consultation around Group mandates meant they were often unsuitable and failed in the local product market. The continuous stream of mandates created work intensification as they typically had to be implemented within tight timelines and the unforeseen mandates were generally not accompanied by additional CAPEX. This often caused Avatar Ireland to reduce certain phases of the local development process, such as testing and functionality, which further exacerbated the likelihood that the mandate would fail in the Irish product market. Avatar Ireland appeared to bear the brunt of failed mandates. For example, at the end of the 2006-2007 financial year Avatar Ireland narrowly missed one of their financial targets. This was reportedly a consequence of a Group request that subsequently failed. Avatar Ireland underperformed by $1.7 \%$ however a decelerating payout formula was used and the employee bonus pool was reduced by $8.5 \%$. A director summarized the general perspective on Group mandates saying:

Group haven't been very helpful by saying the direction is definitely over there and it clearly hasn't been because in every [product] market the direction is subtly different. There have been many changes in the Irish market in the last while which have meant [mandates] have been counter intuitive.

Despite the common failure of mandates Group reportedly had little concern for the Irish product market as a senior manager explained:

What [Group] say is "Well this isn't just about [Ireland's] numbers; this is about something that Avatar can proclaim"... The stock price went through a rather difficult time and we could have been up for a hostile takeover because the company was completely undervalued. Then [Group] had announcements around our technology strategy and how we're moving into [new product and services]. [Group] come out with announcements in order to re-engage the analysts, and get them to rate us higher.

In addition to implementing Group mandates Avatar Ireland was required to develop local revenue generation projects. Avatar Ireland directors and line managers regularly claimed Groups desire to minimize subsidiary CAPEX created a debilitating need to 'prove' return on local CAPEX investment often impeding their ability to compete in the Irish product market. Avatar Ireland allocated CAPEX for local revenue generation projects via a 'Corporate Governance' process. Individuals had to apply for CAPEX via an 'idea specification' document which called for a range of financial analyses including the projected return on investment (ROI) and the cross functional costs, resources and timelines involved. Finance analysts reportedly scrutinized the necessity of each step in the development process. The team of directors collectively approved any project which cost more than one million euro; projects costing less were reviewed by a 'Corporate Governance' committee of two senior managers from finance and one from each other department. A senior manager on the committee explained how:

Unless we can see what the ROI is Corporate Governance won't agree to that particular CAPEX. That's how we manage locally because it comes down from very stringent budget discussions with Group as to how much CAPEX we can have... A huge amount of it comes down to finances because, at the end of the day, our shareholders have to be happy.

Often propositions were revised and re-submitted several times before CAPEX was granted and all individuals going through the process claimed the need for extensive ROI analysis paralyzed local decision-making. The other set of market stories relating to cost cutting, were delivered largely through the budget for operational expenditure.

\section{Controlling cost cutting via the operational expenditure budget}

Avatar Ireland's OPEX budget was targeted for on-going reduction. OPEX reduction targets came largely from Group via benchmarking consultants. Each department in Avatar Ireland was allocated a finance 'business partner' who managed the department's progress against budgets. The Avatar business partner model was publicly celebrated by the Chartered Institute of Management Accountants who heralded it as a 'best practice' example of how accountants can take an active role in leading all areas of the business. In Avatar Ireland, line managers had little input into their operating resources as described by a line manager:

The information I'm getting is that the headcount is set for this, the budget has been set for this, and that the workload has been forecasted for the next couple of years.

The Group led benchmarking process identified headcount reduction opportunities. In the year prior to the ethnography Avatar Ireland reduced OPEX largely via 
redundancies, centralization and outsourcing. The centralization, outsourcing and numerous re-organizations were Group led as one senior manager described:

We're not in total control. We're part of a global entity so we can't call all the shots. All of a sudden we have to implement change that we don't want to implement.

Approximately eighty individuals had been made redundant, approximately sixty were being outsourced and more were in scope for centralization in the coming years. It was widely reported that there was little point in questioning OPEX reduction interventions. A senior manager who had made people redundant stated:

If I'd [failed to make the stated number of people redundant] then the budget next year would be under a challenge ... [... . . . It was put across as a 'fail to comply' that we have to get the number because next year our budget for headcount is $\mathrm{X}$ and that's minus these people.......]...It was handed down as something we had to do, it was done so quickly and then at the end of the day the whole analysis came down and you couldn't see the workings behind the analysis, there was just a [presentation] slide back, there was just a 'here it is'.

There was considerable cynicism regarding the value of the OPEX reduction interventions. Managers claimed that given the nature of the product market and technology, not to mention the unforeseen mandates, future work was unpredictable and cost savings rarely materialized in the manner predicted. For example, the redundancies were justified on the basis that workload in certain teams was going to reduce however it was generally agreed that this reduction had not happened. Certain roles were made redundant only to be re-hired soon after. The continuation of the work levels, the unforeseen Group mandates to develop and launch new technologies and the reduction in resources compounded the work intensification. A senior manager described work levels had:

gone way up to what it was last year and now those people [left behind] are actually putting in longer days...[...]...The work that [benchmarking consultants] did that showed the work dropping off like this, the timing they had on it was totally rubbish.

During the ethnography it was becoming apparent that the outsourcing was proving more costly than expected. This was because the teams that were outsourced were still involved in developing new products and services and the unknown aspects inherent in the work meant that the quotes for work initially provided were inaccurate and projects were running over time and budget. It was also claimed that outsourcing was compounding work intensification as it meant that instead of being able to talk with colleagues individuals in Avatar had to confirm whether work fell within the scope of the outsourcing service agreement and if not quotes for work had to be issued and approved all of which took additional effort and time. Another senior manager described how outsourcing was an important intervention but the cost saving predictions were always dubious:
There would be things like the outsourcing; that were promised to the [financial] market. We understand those. [Group] promised all the synergies and every year we have to do up figures and claim "OK, we made this much" and "Does that equal what we told the market?" Because obviously the worst thing the market can be told is that you didn't achieve your target. . . Employees] understand the logic of it but they don't believe it because outsourcing is about Avatar sitting down and going "OK, over the next ten years this is what we think our development costs are going to be" and they show a graph [going up]. Then the outsourcing company go "Well if you're going to do all of that, we can do it for this [less]". Your outsourcing savings is the gap in between. But you haven't actually done anything...I understand that this is something [Group] have to do for the market because everybody's doing it.

Role insecurity and work intensification was exacerbated by the continuous 're-organizations'. During the 6 month ethnography Avatar Ireland 're-organized' the structure three times meaning roles were assessed and either 'mapped' onto the new structure or 'unmapped' meaning the role was redundant. Individuals in unmapped roles either apply for a 'mapped' role, if available, or accept voluntary redundancy. Work intensification was further exacerbated when, as part of a supply chain agreement, Group introduced new internal technologies and equipment with minimal training. Despite being in a strong profit position OPEX reduction targets meant employee related costs were contained to the minimum of what was required to compete in the external labour market. Salaries were positioned at market median, below target bonuses were paid, lack of formal career progression and training was continually lamented. However Group's stream of constantly changing market stories meant there was little point in attempting to assure employees of their future, as another director stated:

Maybe we should put some simple statement out and we'll pretend it's clear...but that would be telling the kids it'll be alright even though we're driving in the dark and the lights aren't working and Daddy doesn't exactly know where he's going.

Another director stated:

I think [employees] feel Avatar makes money, and they don't feel there's much more than that. I don't feel there's much more than that. I don't think there's a feeling of "We're on a grand mission". Any grand mission is Group saying "We've to reduce costs and Group says we've to go into [technology X]". That's not visionary.

The directors' acknowledged the tensions but continuously accepted Group interventions.

\section{Performative hegemony of financialized interests amongst directors}

In Avatar, Group used a range of short and long term financially indexed incentives to align Group and subsidiary directors with the interests of investors. Group also 
controlled the distribution of resources. While this might partly explain directors acceptance of financial targets it says little about the day to day 'micro-politics' and tensions that shape the relationship between MNC parents and subsidiaries (Dörrenbächer \& Geppert, 2006). All Avatar Ireland directors professed to support Group strategy; however Irish directors were far more likely to explain how Group appointed expatriates on the Irish team of directors meant local decision making was oriented in Groups favour despite it regularly not making financial sense. During the ethnography, four of the seven members of the Avatar Ireland team of directors were appointed to Ireland from Group. The roles with key decision making authority, namely the Chief Executive Officer (CEO) and Chief Financial Officer (CFO) were filled by individuals appointed from Group. After a number of years, usually three to four, expatriates typically went on to larger roles either within Group or another subsidiary. The impact of an ex expatriate Avatar Ireland CEO was described by an Irish director:

For him it was always very important that we [implemented Group mandates] even though commercially it sometimes didn't seem to make any sense because you'd invest massive amounts into a product that sometimes didn't work very well and there would be a lot of people at the [Irish directors] table saying "This is a heap of crap we're never going to make any money on this". But it would still be "Look you know we have to do this". So we'd do it and we wouldn't make any money and it would be "We told you so". But we had to be good corporate citizens and I think there would have been more resistance if you didn't have someone like him there because he was not going to start being exceptionally defiant.

There was a widely held view that expatriates were not concerned about the consequences of Group interventions on lower levels. Indeed, Group appointed directors were more likely to express irritation when questioned about whether the pursuit of financial targets had negative consequences. They typically responded by discussing the financial importance of such interventions and how there was no alternative. The dominance of expatriate directors, in numbers and status, in conjunction with the budgeting process, meant Group narratives and interventions attained performative hegemony within this key exchange relationship. The consequences of this were lived out by lower levels.

\section{Budgets as a financialized performative mechanism within the knowledge labour process}

The dual market stories relating to revenue generation and cost cutting meant Avatar Ireland was working to achieve two contrasting goals. Many roles contributed to both but were weighted more in favour of one creating the unofficial categories of knowledge work which are termed here as 'generative' and 'operational' work. Generative work is future oriented and involves generating change such as creating a new product, service or process.
Employees undertaking generative work use their knowledge to research, analyze, provide ideas, proposals, business cases, project plans and undertake project work. After new products, services or processes were developed the integration and ongoing execution of them became the domain of 'operational' knowledge work. Operational work is oriented in the present and involves executing the on-going processes and activities required for the effective operation of the organization. Employees undertaking operational work use their knowledge to complete known, yet complex, work processes, achieving performance standards and resolving complexities arising along the way. Within Avatar the split between generative and operational work appeared to be approximately 60:40 in favour of generative work. The constant change meant that both categories of work involved applying a body of theoretical (specialized and abstract) knowledge to continuously innovate products and processes. Both categories were made up of employees from a range of professions, for example, there were accountants, engineers and marketers on operational and generative teams; they were equal in terms of explicit knowledge. Furthermore all labour costs such as payroll and training for both categories were funded by OPEX and neither category was shielded from the cost reductions, reorganizations and the associated insecurity. A key difference between the categories was that CAPEX was funded generative projects and this had significant consequences for the labour process.

\section{Generative knowledge workers: 'Loud and Proud'}

The market story guiding generative work centered on the return on CAPEX investment. Generative work related primarily to generating new revenue and emerged from Group mandates and locally generated projects that reflected Group strategy. It was organized in projects which were funded by CAPEX. Generative teams competed for CAPEX, as one generative employee commented 'There's a lot [of people] up there competing for the same cash from the same pool'. In order to secure CAPEX, via the previously described corporate governance process, employees contributed to the development of the proposition business case. Generative projects were developed via a 'release management' system and progress on projects was reported in intervals known as 'tollgates' when expenditure and progress was reviewed. This meant knowledge workers from non-financial backgrounds, such as marketing and engineering, were required to work with financial analysts to translate their knowledge into convincing, strategically aligned, budgetary 'return on investment' business cases. Generative work involved significant cross functional work in order to identify the organization wide activities required to deliver a project. The unpredictability inherent in doing something new meant no business case or project was failsafe and generative teams sought to fill the indeterminacy by shrouding their business cases, and tollgate reports in un-contradicted, wholly optimistic narratives relating to return on investment. In order to create these optimistic narratives generative employees actively 'canvassed' support for their proposition, to 'sell' it or get 'buy in' and this created a need to develop informal, subtle, 
organization wide networks. There were two terms widely used to denote the behaviours required to enhance a generative employee's ability to garner the cross functional support required to have their propositions funded, developed and to get interesting work on new projects. These were 'managing upwards' and 'profiling'. Managing upwards can be understood as the action an individual undertakes to prioritize and express their work in a way that demonstrates commitment to management objectives. Managing upwards reportedly involved prioritizing the interests of senior personnel above peers. It shaped how work was expressed as it involved convincingly translating and communicating work so the strategic contribution was knowable to management as a generative employee summarized:

It's a lot of presenting. We do PowerPoint like you've never seen in Avatar. It's getting in front of people, it's talking, it's sending emails to people, it's driving the project forward, it's keeping the right people informed of the progress on the project. You would do that through presentations into the marketing management team, the sales and customer management department, or into technology or then into the directors or into the relevant governance body.

The second behaviour of 'profiling' can be understood as the action an individual undertakes to heighten the perceived value of their work throughout the organization. Whereas managing upwards shaped how work was prioritized and expressed, profiling was about being loud as a generative employee described:

You get yourself out there, you get yourself known. You get whatever you're given delivered but you make sure everybody knows about it, even in areas that they don't need to know, you make your name known.

The pace of change and tight resources meant that employees had to prioritize work and having a profile meant that others assumed the work was of value and making them more willing to provide support. Extensive communications were also required for profiling including emailing, having coffees, holding and attending meetings. Managing upwards and profiling involved being visible and making noise in order to secure CAPEX, get through tollgates, get interesting work on high profile projects. Managers agreed that these behaviours were rampant and, given the pace of change and re-organizations, they were critical to securing one's position in Avatar as one senior manager described:

What [employees] definitely need to get on is the ability to promote yourself and manage up. There is no doubt about that, because this is such a big organization and there's so many people here that you have to make yourself known and you have to make yourself heard, and you have to involve yourself because a lot of people get walked over and a lot of people get pushed aside or taken for granted or advantage of.

Generative employees also reported that when generative projects failed to realize the desired levels of return on investment they were in a vulnerable position in the performance review process. Ultimately generative employees could not be certain about what they would be working on in the future and whether this work would be valued. This, in addition to the insecurity created by the re-organizations, meant the generative knowledge labour process was rife with ambiguity and uncertainty. The primary method available to generative employees to secure their role in the organization was to continuously orient their efforts to and vocally support the organization strategy. This was how Groups financialized narratives became performative within the generative labour process. However this same process also had counter-performative consequences. The newness of generative work combined with the wholly optimistic business cases and reluctance to critique work meant potential problems often went ignored causing projects to regularly go over budget, over time and even fail. During one corporate governance meeting the committee discussed how there was no way of telling what the current release would end up costing. Once a generative project was launched the ongoing delivery and maintenance of the new product, service or processes became the responsibility of operational knowledge workers.

\section{Operational knowledge workers: 'Seen but not Heard'}

Operational work was about business as usual and was funded solely by OPEX; the market story guiding OPEX was cost reduction. Operational teams were tasked with adhering to pre-established service level agreements (SLAs) whilst integrating a constant stream of new processes, products and services into the existing infrastructure amidst ever diminishing resources. Whereas there was an acknowledged uncertainty regarding the outcome of generative work, benchmarking meant operational work was deemed to be more achievable thereby requiring less input from senior management. IT based workflow management systems were used to coordinate the flow of operational work and to track progress against SLAs. The budget and performance targets shaping operational work came largely from Group and the benchmarking process meaning they were deemed a fait accompli. As operational targets were deemed to be more knowable operational employees were to be quiet and compliant, seen but not heard. The fact that tacit knowledge, judgement and flexibility were required for operational targets to be met amidst continuously changing organizational structures, technologies, products, services, processes, minimal training and depleting resources appeared to go unrecognized. The anaemic resources available to undertake operational work meant that prioritizing and permitting backlogs of work were typical features of operational work. Many operational employees and line managers felt overburdened and compromised. The minimal training on new technologies meant that teams began to develop specialists rather than generalists and work got further delayed when trained employees were unavailable as an operational line manager stated 'It's just constantly flat-out, I mean constantly re-prioritizing work'.

Operational teams did not need to court favour to secure CAPEX investment and continuously expressed concern that the technical infrastructure was being 
compromised as they were only completing priority work. This created tensions between the two categories as generative teams, in their desire to create wholly optimistic business cases, often ignored operational concerns about propositions as described by an operational line manager:

[Generative teams] would end up forcing a lot down to us giving us unrealistic launch dates and sort of saying "Well look, we've committed to this date, we have to have this service launched by day X". We know ourselves, as engineers I mean "look, what you're asking is, well it's not impossible but you're going to put in a system that isn't really suitable for what you need". That has happened on so many occasions...[...]...Momentum gets built up behind this project long before operations ever gets sight of it and then it's just this avalanche coming down.

Celebratory corporate communications focused primarily on generative work as the launch of a new technology was a more positive story than celebrating how an operational team met their SLAs despite losing team members to redundancy and without the training required to do their job. Operational employees had no control over the work that came their way however they were certain their work was not sufficiently valued. This, in addition to the insecurity created by the re-organizations and focus on reducing operational costs, meant the operational knowledge labour process was rife with work intensification and uncertainty. The primary method available to operational employees to enhance their role in the organization and prevent them from being seen as a costly difficult burden that should be centralized or outsourced was to suppress their missgivings about generative work and continuously meet ever changing targets. This was how Groups financialized narratives became performative within the operational labour process. However this same process also had counter-performative consequences. The inability of operational workers to voice their concerns diminished the long-term viability of the organizations technical and procedural infrastructure.

Direct and responsible accountability in the knowledge labour process

The Avatar case demonstrates how financial markets can dominate the organization of knowledge work over and above the product market creating a distinct, tension filled, financialized knowledge labour process. Seminal labour process writings by Friedman outline two managerial strategies to managing the labour process namely 'direct control' and 'responsible autonomy'. Friedman's work highlighted the relationship between the control of production work and an organization's position in the product market; before financialization became the prevailing mode of capital accumulation. A characteristic of knowledge work is that it is more amenable to 'results controls' than 'action controls' (Bryer, 2006). What separated the two categories of knowledge work in Avatar was the extent to which the results were deemed programmable and achievable and this in turn shaped how employees were held 'accountable' (Bryer, 2006). Benchmarking meant cost reduction was deemed a wholly achievable result as it involved removing costs the benchmarking process identified as inefficient. The benchmarking process was positioned by Group and directors, as an accurate depiction of the level of resources required to achieve results and operational workers were 'directly accountable' for these results. This accountability existed despite mangers claiming the methodology and application of benchmarking was flawed. Generative work was about creating something new, primarily to generate new revenue and achieve a positive ROI. However there was less certainty that generative work would achieve the desired ROI in the product market. The lack of certainty meant generative workers were held 'responsibly accountable' meaning they were expected to continuously demonstrate they were responsibly scrutinizing their work against ROI principles and keeping to budget in the release management process. If a generative project failed employees had to seek out alternative routes to achieve results. As generative results were less programmable directors controlled the CAPEX invested in generative work and monitored subsequent projects closely. This is not to say that the product market defined generative work. Both categories of work served the same product market and both were required to deliver continuous change. It was the market story and subsequent calculative equipment that affected the extent to which employees could be held accountable for their actions. Bryer argues that accounting can represent 'the 'totality' of control of the labour process which 'institutionalises the subordination of labour' by making labour wholly accountable to capital' (2006: 552). In Avatar market stories played a dominant role in organizing work over and above product markets and accounting practices rendered employees either directly or responsibly accountable for their contribution to these stories.

\section{Financialization, competing narratives and the insecure, angry knowledge worker}

\section{Competing narratives}

Within Avatar optimistic narratives relating to 'best practice' human resource management were competing to exist alongside the financialized narratives and subsequent performative interventions. Avatar Group heralded the importance of 'employee engagement' in annual reports and their aim was for engagement, as measured by external consultants, to be in the top quartile in each subsidiary. HR practices were described and celebrated in annual reports as an indication that Avatar was a value driven, globally aligned, committed organization. Group Human Resources (HR) directed subsidiary people management practices. They won external awards for their employee communications which were described as 'stunning' and 'inspiring'. Group people management practices featured in 'best HR practice' publications produced by the Chartered Institute of Personnel and Development. A 'People Strategy' claimed that Avatar was a meritocracy and employees were in control of their destiny. The Avatar Ireland HR practices ranked in the top 5\% in the Irish 'Great 
Place to Work' competition and benchmarking revealed that the Avatar Ireland HR department was larger than what was typical for an organization of their size and sector. Group developed an explicit global employer brand which detailed the desired behavioural traits of employees (Cushen, 2009). The employer brand also served as a communications framework meaning all decisions were portrayed as being 'on brand' thus signifying decisions were positive regardless of consequences as described by a senior HR manager:

'We find it hard to say that things are not going as well as we thought they would...We try and put a gloss on it. We'd say "Well actually this is good news that we're going to [for example] outsource the IT department".

All directors adhered to the optimistic communication conventions. The official name of the redundancy program was 'Shaping our Future' and it was referred to as an achievement Avatar Ireland should be proud of, outsourcing was portrayed as an opportunity for career development and centralization was a positive development. The optimistic narrative glossed over the negative consequences of decisions which were referred to only as 'challenges'; challenges were then portrayed as wholly positive, valuable opportunities for personal growth. When talking about the recent cost cutting and resulting job insecurity one director stated 'I think a lot of people mistake what's gone on in the last 12 to 18 months. If you're someone who likes a challenge it's a challenging business'.

\section{The angry insecure knowledge worker}

Far from being in the upper quartile, engagement in Avatar Ireland had been lower than the national average for a number of years. Some of the lowest scores related directly to the upheaval and insecurity driven by the market stories. In terms of the constant change, $38 \%$ of employees had a favourable opinion of how change was managed. In terms of employment, financial and role security, $34 \%$ felt they had a future in Avatar, 25\% had a favourable perception of their opportunity for promotion and 36\% felt their total reward package was fair when compared to similar roles in other organizations. Despite being a high-technology organization, only $21 \%$ of employees from the technology department felt they had the training to do their job. Employees expressed less trust and confidence in Group management and local directors than in lower levels of management. However there was no ambiguity about performance expectations and the highest positive survey response related to the statement 'I know the results expected of me in my job' to which $85 \%$ indicated that they 'more than agreed'. The second highest was 'I understand why cost effectiveness is a key strategic objective for Avatar Ireland' to which $84 \%$ agreed. It was not possible to segment the employee survey by the categories of knowledge work however in interviews employees from each category offered similar perspectives. Generative workers were not more secure in their job, nor were they in receipt of higher remuneration. The higher status afforded to generative work was undermined by employees' perception that managing upwards and profiling nurtured falseness, dishonesty and lack of genuine social ties within the organization. All but one interviewee condemned the need to profile and manage upwards. Operational workers reported stronger social ties within their own teams but resented their lack of voice in the organization.

In interviews employees typically attributed the survey results to the hegemonic force of financial targets. Employees claimed top management were only concerned with, as one employee stated 'money, cost cutting, improving the share price'. Far from having their subjectivity appropriated by the HR narrative employees could rationally articulate how financialized capitalism structurally prioritized shareholder interests as was articulated by another employee:

Let's be honest, at the end of the day if a company's quoted on the stock exchange, it answers to shareholders. ...... . . If the shareholders are feeding back to Ava$\operatorname{tar}[$ Group] ... [...]. . .that their labour costs are too high and that they need to reduce operational expenditure; it's only a matter of time and unfortunately that is the nature of the beast...[...]...I must say the company did not communicate it that way. It's my take on the situation. I didn't dream it up, I didn't read it on Google last night. My take is backed up with years of reading; I have got [multiple degrees]. So these aren't just words I throw out, these are a belief system, 'the shareholder is king' and they are.

In terms of market stories relating to revenue generation employees were exasperated by the continuous change and hyping of generative propositions as the 'next big thing', the work intensification and the silence over wastage of CAPEX when propositions failed. The cost cutting meant employment insecurity was rife as employees continually claimed that Group could outsource, centralize, reduce headcount or even close the subsidiary at any moment. The continuous re-organizations resulted in 'role insecurity' as re-organizations rendered employees' role and status in the organization unstable even where employment security was not officially threatened. Reorganizations were often implemented within tight timelines and without consultation meaning mistakes were made and decisions were often reversed or changed numerous times. Whole teams would vanish, only to reappear later when it was brought to managements' attention and this created significant resentment amongst employees and repeated claims that management were 'making it up as they went along'. Financial insecurity was also prevalent and employees expressed contempt for the median levels of remuneration given the significant profit levels achieved in Avatar Ireland. The pervasive insecurity clashed with the baselessly optimistic HR narrative to provoke anger and vitriol. A handful of studies explore how corporate cultural narratives can be met with employee cynicism characterized as a distrust of motives (Fleming \& Spicer, 2003; McCabe, 2011). However the employee sentiment in Avatar went beyond cynicism. The HR narrative was interpreted as an indication that not only did Group and directors afford employees little consideration in decision making but they did not respect employees enough to acknowledge any negative consequences. The 
excessive optimism was considered a hypocritical affront to their understanding of themselves as intelligent, educated professionals as another employee stated:

For professionals like me or relatively intelligent people it really is insulting...[...]... I've been to college and I've done all these things and I've qualified and there's people even more qualified than me and they're suffering this.

The optimistic narrative was interpreted as a sign that higher management considered employees to be 'of below average intelligence' unable appreciate their material reality of their employment:

They're telling you one day how important you are to them and the next day they're making more redundant. They're telling you there's not enough people to do the job, and they're agreeing that they're trying to do something about it. Then they're letting all these people go and they're not taking people on to replace them. It's just hypocrisy after hypocrisy; they don't eat their own dog food.

Communication events in Avatar Ireland were poorly attended as they were considered infuriating, one employee described how when at one event the HR director claimed the redundancies should be viewed as an achievement they wanted to shout out:

You are so out of touch. You're actually meant to be in charge of the people, not the profit or the margin or whatever else, you're actually meant to be in charge of the actual human beings in the building and you're so out of touch.

Employees' rejection of the human resource narrative resembles Knights and Collinson's (1987) account of how financial narratives can discipline workers over and above a human relations narrative. In Avatar the human resource narrative was universally rejected by all knowledge workers as it was considered a contemptuous insult to their informed, educated ability to understand the model of capitalism they were operating within and the subsequent insecure 'reality' of their employment. Ultimately employees were insecure, angry and understood themselves as a distinct, vulnerable organization stakeholder whose interests were marginalized. One employee neatly summarized the general sentiment:

Employee: Avatar doesn't have any heart and soul and it's not really somewhere I want to be long term.

Author: You say it doesn't have any 'heart and soul'; what's there in its place?

Employee: Capitalism...isn't it everywhere.

\section{Hegemonic struggles, counter-performativity and resistance}

The Avatar case highlights the pertinence of Gramsican dialectics whereby hegemony should not be equated with ideological domination. Mumby (1997) calls for examination of the 'hegemonic struggle' which is 'concerned with the extent to which actors can discursively penetrate their material conditions (Mumby, 1997: 350). The Avatar employment experience was defined precisely by the tensions arising from the hegemonic struggle. The performative hegemony of the financialized narrative created the pervasive insecurity as employees were painfully aware of the commodified, insecure status of their employment. The second tension was caused by the clash of narratives whereby the optimistic financial and HR narratives were so contradictory to employees' lived experience of the performative interventions it was considered a repellant affront to their intelligence.

However employees also claimed there was little point in overtly resisting or critiquing the financialized performative interventions as targets were a fait accompli long before they reached employees. The employee survey was the primary avenue for capturing employee voice and the survey revealed that $37 \%$ felt the information used from previous employee surveys was used. However the reluctance to openly critique Group mandates and locally generated ideas also had counter-performative consequences as it meant potential problems often went ignored enhancing the likelihood that new products and services would fail and diminishing the long-term viability of the organizations infrastructure. The reluctance to critique also allowed employees to distance themselves from managerial objectives. Remaining quiet became a form of resistance through work avoidance as some employees claimed it was possible to find solutions to problems but they felt no inclination to put in the required effort, as one employee described:

What's the point anyway?... It's not my problem, once my parts of it work I don't really care if it's a great success or it falls flat on its face.

Numerous projects went significantly awry during the course of the ethnography. Prior to the launch of these projects problems were reportedly predicted but were never raised with directors. These projects were labelled, what one director called, 'plausible failures' whereby it was difficult to apportion blame for a failure as the problem had never been identified. For employees, fake positivity was both a form of work avoidance and a form of self-protection as one senior manager stated 'It's very hard to give negative feedback to a positive person'.

\section{Discussion and conclusion}

Fig. 2 sets out the performative trajectory of financialization in Avatar. The Avatar case demonstrates how financialization elevates the role of accounting in organizations. Financialization is a performative phenomenon and accounting targets are is the starting point, the vehicle and the destination.

Avatar top management were facing a dilemma that typifies financialized capitalism namely financial actors sought levels of financial returns beyond what the product market could deliver. In the financial year preceding the ethnography Avatar Group generated approximately thirty billion in revenue and ten billion in operating profit. Nonetheless investor scepticism regarding Avatar's ability to grow revenue prompted share price volatility. This 


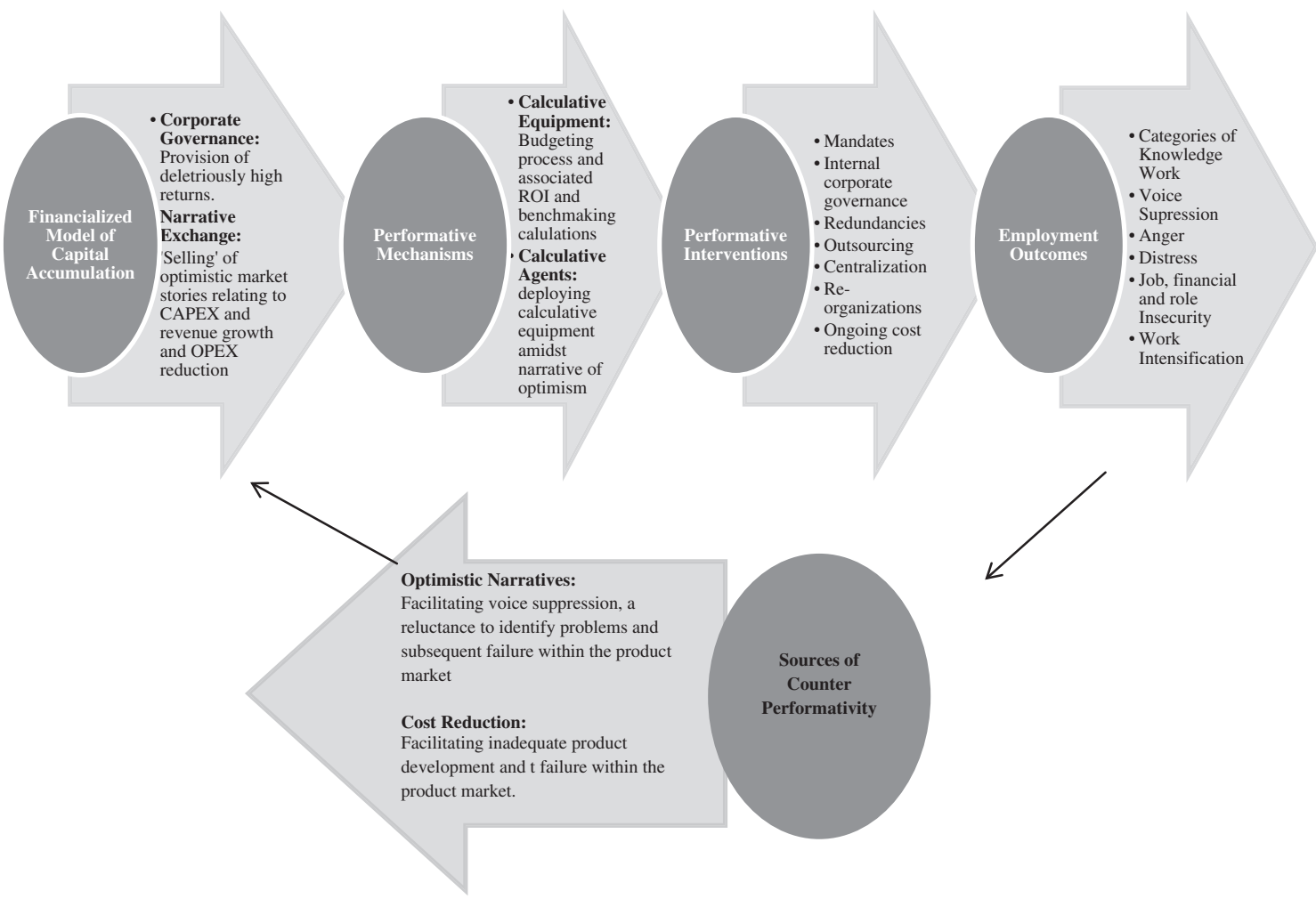

Fig. 2. Performative trajectory of financialization in Avatar.

prompted top management to provide deleteriously high dividends and to script ever changing optimistic narratives about future revenue growth and cost cutting. This paper demonstrates that financialization in organizations is defined by the performative interventions taken in an attempt to make the organization become the model of shareholder value creation management narratives claim it to be; as Callon states 'the world conveyed by the statement is only realized after a long collective effort' (2007: 313). Consequently, exploring how interventions are coordinated, received, challenged and sustained yields insights into how financialization achieves performative hegemony within organizations. In Avatar Ireland these performative interventions included continuous Group mandated changes to products and services, locally developed revenue generating initiatives, redundancies, outsourcing, centralization, re-organizations and on-going reduction of operational expenditure.

The paper documents how budgeting practices served as the performative mechanism through which this myriad of performative interventions were transmitted and delivered by lower levels. In his explorations of how hegemonic systems emerge Mumby states 'the groups with the most power will be those that are best able to integrate their sectional claims into the very structuring of the organisation' (1987: 116). The Avatar case identifies how budgets enable the structures and narratives which prioritize capital interests at the corporate governance level to be replicated inside the organization. In Avatar subsidiary directors were required to continuously justify and reduce subsidiary expenditure, craft optimistic narratives and achieve a myriad of performative interventions to secure capital investment from Group. Line managers and employees were required to deliver ever changing performative interventions, cut costs and also craft optimistic narratives to secure capital investment and work on projects. In Avatar a 'continuous budgeting' (Frow et al., 2010) process was leveraged by management to the establish structures and calculative equipment that enabled them to pass down and continually scrutinize progress against ever changing performative interventions.

The paper also highlights how financial narratives and accounting practices can dominate the knowledge labour process. All roles in Avatar contributed to the revenue generating and cost cutting market stories but were weighted more in favour of one resulting in the categories of generative and operational knowledge work. The approach taken to control work was based on the extent to which accounting practices rendered desired results knowable to management. The lack of certainty in generative work meant employees were held 'responsibly accountable' required to continuously demonstrate responsible minimization of risk through ongoing scrutiny of their work against ROI principles. Operational outcomes were deemed wholly achievable and operational workers were held 'directly accountable' for achieving operational targets. The accounting practices also created behavioural scripts whereby generative workers were required to loudly 'manage upwards' and 'profile' and operational workers were to be quiet and compliant. Both behaviours prompted 
suppression of voice and a reluctance to highlight concerns. In Avatar the performative interventions created constant, not just change, but upheaval in the labour process. The case demonstrates how embedding accounting practices at the core of the labour process can compel employees to comprehend change and their contribution to it in terms of costs and ROI; thereby rendering financial measures omnipotent amidst continuous upheaval.

Finally the paper documents how performative interventions created the employment outcomes associated with financialization. By specifying how these outcomes came about the Avatar case highlights that financialization, in addition to creating employment insecurity, financial insecurity and work intensification, can also prompt role insecurity, suppression of voice and enactment of falsely optimistic behaviours. The continuous stream of performative interventions caused employees to feel anything could happen to their role at a moment's notice; the cumulative effect of which was insecurity and distress. This distress was exacerbated by the competing high road HR narrative which was considered an affront to their informed ability to discern the material 'reality' of their employment conditions within financialized capitalism. The clash of narratives defined the employment experience creating a perception that management first did not value employees and secondly considered employees to be naïve and even stupid. Contrary to the knowledge based literature employment in knowledge intensive organizations need not be characterized by secure, empowering employment. Within financialization knowledge and knowledge workers, as a source of organization success, are secondary to the appeasement of financial actors. Instead, the daily mindset of knowledge workers labouring within a financialized organization can be one of anger and distress. Nonetheless employees can participate in their subordination and accept the financialized narratives and performative interventions if they interpret them as the primary method of securing their role in a pervasively insecure organization. This is how financialization achieved performative hegemony within Avatar.

Hegemony is never automatic and performative does not mean prophetic. In Avatar the avoidance of open critique enabled the hegemony of financialized interests but also had counter-performative consequences as it meant potential problems often went ignored enhancing the risk of failure in the product market and diminishing the long-term viability of the organizations infrastructure. The reluctance to critique also allowed employees to distance themselves from managerial objectives and became a form of resistance through work avoidance. Identifying 'counter performative' outcomes is a valuable step as it draws attention to the unintended consequences of financialization and prompts consideration of the acceptability of these consequences. The Avatar case demonstrates how counter performativity and resistance can simultaneously weaken and perpetuate the performative hegemony of financialized interests.

Avatar was one organization operating at a specific point in time. However the manner in which the findings corroborate other literatures points to the wider relevance of the case. More micro level studies, perhaps of singular interventions, could shed additional light on the ways financialization is transmitted, mediated, challenged and sustained in workplaces.

As the Saramago quote posited at the outset 'only the best bosses can combine contrary feelings'. The performative hegemony of financialized interests in Avatar resulted in the marginalization of contrasting feelings and interests; to the detriment of employees. Financialization can place real limits on the extent to which organizations can combine contrasting interests and be a 'good boss'. In the financialized workplace investors dominate, accounting narratives permeate and knowledge workers are not that special after all.

\section{References}

Aglietta, M., \& Breton, R. (2001). Financial systems, corporate control and capital accumulation. Economy and Society, 30(4), 433-466.

Ahrens, T., \& Chapman, C. (2006). Management accounting as practice. Accounting, Organizations and Society, 32, 21-27.

Akbar, S., Zulfiqar, S., Shah, A., \& Saadi, I. (2008). Stock market reaction to capital expenditure announcements by UK firms. Applied Financial Economics, 18, 617-627.

Alvehus, J., \& Spicer, A. (2012). Financialization as a strategy of workplace control in professional service firms. Critical Perspectives on Accounting, 23(7), 497-510.

Alvesson, M. (2001). Knowledge work: Ambiguity, image and identity. Human Relations (54), 863-886.

Andersson, T., Haslam, C., Tsitsianis, N., \& Lee, E. (2008). Financialization directing strategy. Accounting Forum, 32(4), 261-275 (15 p.).

Andersson, T., Lee, E., Theodosopoulos, G., Yin, Y. P., \& Haslam, C. (2012). Accounting for the financialized UK and US business model. Critical Perspectives in Accounting. <http://dx.doi.org/10.1016/ j.cpa.2012.10.006>.

Appelbaum, E., Batt, R., \& Clark, I. (2013). Implications of financial capitalism for employment relations research: Evidence from breach of trust and implicit contracts in private equity buyouts. British Journal of Industrial Relations. http://dx.doi.org/10.1111/bjir.12009.

Batt, R., \& Appelbaum, E. (2013). The impact of financialization on management and employment outcomes. Upjohn working papers and journal articles 13-191. W.E. Upjohn Institute for Employment Research.

Bezereh, M. J., \& Goldstein, J. P. (2013). Real and financial determinants of the profit share: The financial profit squeeze. PERI working paper number 307

Boyer, R. (2000). Is a finance-led growth regime a viable alternative to fordism?: A preliminary analysis. Economy and Society, 29, 111-145.

Briers, M., \& Chua, W. F. (2001). The role of actor-networks and boundary objects in management accounting change: A field study of an implementation of activity-based costing. Accounting, Organizations and Society, 26, 237-269.

Bryer, R. (2006). Accounting and control of the labour process. Critical Perspectives on Accounting, 17(5), 551-598.

Burchell, B., Ladipo, D., \& Wilkinson, F. (2002). Job insecurity and work intensification. London: Routledge.

Callon, M. (Ed.). (1998). The laws of the markets. Oxford: Blackwell.

Callon, M. (2007). What does it mean to say that economics is performative? In D. MacKenzie, F. Muniesa, \& L. Siu (Eds.), Do economists make markets? On the performativity of economics (pp. 311-357). Princeton/Oxford: Princeton University Press.

Carr, C., \& Tomkins, C. (1998). Context, culture and the role of the capital function in strategic decisions: A comparative analysis of Britain, Germany, the USA and Japan. Management Accounting Research, 9, 213-239.

Cooper, D. J., \& Hopper, T. (2007). Critical theorising in management accounting research. Hanbook of Management Accounting Research, 1, 207-245.

Cushen, J. (2009). Branding employees. Qualitative Research in Accounting $\mathcal{E}$ Management, 6(1/2), 102-114.

Cushen, J., \& Thompson, P. (2012). Doing the right thing? HRM and the angry knowledge worker. New Technology, Work and Employment, 27(2), 79-92.

Czarniawska, B. (1997). Narrating the organization: Dramas of institutional identity. Chicago: The University of Chicago Press. 
Davis, G. F., \& Marquis, C. (2005). Prospects for organization theory in the early twenty-first century: Institutional fields and mechanisms. Organization Science, 16, 332-343.

Deem, R. (2004). The knowledge worker, the manager-academic and the contemporary UK university: New and old forms of public management? Financial Accountability \& Management, 20(2), $107-128$.

Dobbin, F. (2005). Comparative and historical approaches to economic sociology. In N. J. Smelser \& R. Swedberg (Eds.), The handbook of economic sociology (2nd ed.. Princeton: Princeton University Press.

Dobbin, F., \& Jung, J. (2010). 'The misapplication of Mr. Michael Jensen: How agency theory brought down the economy and why it might again' in 'Markets on trial: The economic sociology of the U.S financial crisis'. Research in the Sociology of Organizations, 30B, 29-64.

Dörrenbächer, C., \& Geppert, M. (2006). Micro-politics and conflicts in multinational corporations: Current debates, re-framing, and contributions of this special issue. Journal of International Management, 12(3), 251-265.

Drucker, P. F. (1996). The shape of things to come: An interview with Peter Drucker. Leader to Leader, 12-18.

Dünhaupt, P. (2013). The effect of financialization on labor's share of income (No. 17/2013). Working paper. Institute for International Political Economy Berlin.

Epstein, G. A. (2005). Introduction: Financialization and the world economy. In G. A. Epstein (Ed.), Financialization and the world economy. Cheltenham and Northampton, MA: Edward Elgar.

Erturk, I., Froud, J., Johal, S., Leaver, A., \& Williams, K. (2008). Financialization at work: Key texts and commentary. Oxfordshire: Routledge.

Ezzamel, M., Wilmott, H., \& Worthington, F. (2008). Manufacturing shareholder value: The role of accounting in organizational transformation. Accounting, Organizations and Society, 33, 107-140.

Farber, H., \& Hallock, K. F. (1999). Changing stock market response to announcements of job loss: Evidence from 1970-1997. Industrial relations. Working paper no. 793. Princeton University, New Jersey.

Faulconbridge, J. R., \& Muzio, D. (2009). The financialization of large law firms: Situated discourses and practices of reorganization. Journal of Economic Geography, 9, 641-661.

Fleming, P., \& Spicer, A. (2003). Working at a cynical distance: Implications for the power, subjectivity and resistance. Organization, $10,157-179$.

Foster, J. B. (2007). The financialization of capitalism. Monthly Review, 58 11.

Froud, J., Johal, S., Leaver, A., \& Williams, K. (2006). Financialization and strategy: Narrative and numbers. London: Routledge.

Froud, J., Haslam, C., Johal, S., \& Williams, K. (2000). Restructuring for shareholder value and its implications for labour. Cambridge Journal of Economics, 24, 771-797.

Frow, N., Marginson, D., \& Ogden, S. (2010). “Continuous” budgeting: Reconciling budget flexibility with budgetary control. Accounting Organizations and Society, 4(35), 444-461.

Giroux, H. A., \& Myrsiades, K. (2001). Beyond the corporate university: Culture and pedagogy in the new millennium. Rowman \& Littlefield.

Gleadle, P., \& Cornelius, N. (2008). A case study of financialization and EVA $^{\circledR}$. Critical Perspectives on Accounting, 19(8), 1219-1238.

Gleadle, P., \& Haslam, C. (2010). An exploratory study of an early stage R\&D-intensive firm under financialization. Accounting Forum, 34, 54-65.

Gomez, P. Y. (2004). On the discretionary power of top executives: Evolution of the theoretical foundations. International Studies of Management and Organization, 34(2), 37-62.

Gospel, H., \& Pendleton, A. (2003). Finance, corporate governance and the management of labour: A conceptual and comparative analysis. British Journal of Industrial Relations, 41, 557-582.

Gramsci, A. (1971). In G. N. Smith, \& Q. Hoare (Eds. and Trans.), Selections from the prison notebooks of Antonio Gramsci. International Publishers.

Gupta, A. (2012). What the market likes: External learning and firm valuation.

Harney, B., Monks, K., Alexopoulos, A., Buckley, F., \& Hogan, T. (2011) University research scientists as knowledge workers: Contract status and employment opportunities. The International Journal of Human Resource Management, ahead-of-print, 1-15.

Hendry, J., Sanderson, P., Barker, R., \& Roberts, J. (2006). Owners or traders? Conceptualizations of institutional investors and their relationship with corporate managers'. Human Relations, 59(8), 1101-1131.

Hernes, G. (1998). Real virtuality. In P. Hedstrom \& R. Swedberg (Eds.) Social mechanisms: An analytical approach to social theory (pp. 74-101). New York: Cambridge University Press.
Jackson, G. (2005). Towards a comparative perspective on corporate governance and labour management: Enterprise coalitions and national trajectories. In H. Gospel \& A. Pendleton (Eds.), Corporate governance and labour management: An international comparison. Oxford: Oxford University Press.

Kalleberg, A. (2010). Good jobs, bad jobs: The rise of polarized and precarious employment systems in the United States, 1970s-2000. New York: Russell Sage Foundation Publications.

Knights, D., \& Collinson, D. (1987). Disciplining the shopfloor: A comparison of the disciplinary effectives of managerial psychology and financial accounting. Accounting, Organizations and Society, 12(5), 457-477.

Kunda, G., \& Ailon-Souday, G. (2005). Managers, markets and ideologies: Design and devotion revisited. In S. Ackroyd, R. Batt, P. Thompson, \& P. Tolbert (Eds.), Oxford handbook of work and organization (pp. 200-219). Oxford: Oxford University Press.

Lam, A. (2000). Tacit knowledge, organizational learning and societal institutions: An integrated framework. Organization Studies, 21 487-513.

Langley, P. (2004). In the eye of the "perfect storm": The final salary pensions crisis and the financialization of Anglo-American capitalism. New Political Economy, 9, 539-558.

Lapavitsas, C. (2011). Theorizing financialization. Work Employment and Society, 25(4), 611-626.

Lazonick, W. (2012). The financialization of the US Corporation: What has been lost, and how it can be regained. MPRA paper no. 72307

Lutz, S. (2004). Convergence within national diversity: The regulatory state in finance. Journal of Public Policy, 24, 169-197.

MacKenzie, D. (2007). Is economics performative? Option theory and the construction of derivatives markets. In D. MacKenzie, F. Muniesa, \& L Siu (Eds.), Do economists make markets? On the performativity of economics (pp. 311-357). Princeton/Oxford: Princeton University Press.

McCabe, D. (2011). Accounting for consent: Exploring the reproduction of the labour process. Sociology, 45(3), 430-446.

McCann, L. (2013). Disconnected amid the networks and chains Employee detachment from company and union after offshoring. British Journal of Industrial Relations. http://dx.doi.org/10.1111/ bjir.12014.

Milberg, W., \& Winkler, D. (2009). Financialization and the dynamics of offshoring. Cambridge Journal of Economics (March), 1-19.

Miller, P., \& O'Leary, T. (2005). Capital budgeting, coordination and strategy: A field study of interfirm and intrafirm mechanisms. In C. S. Chapman (Ed.), Controlling strategy: Management accounting and performance measurement (pp. 151-182). New York: Oxford University Press.

Mintzberg, H., Simons, R., \& Basu, K. (2002). Beyond selfishness. Mit Sloan Management Review, 44, 67-74.

Mumby, D. K. (1987). The political function of narrative in organizations Communications Monographs, 54(2), 113-127.

Mumby, D. K. (1997). The problem of hegemony: Rereading Gramsci for organizational communication studies. Western Journal of Communication, 61(4), 343-375.

O'Neill, P. (2001). Financial narratives of the modern corporation. Journal of Economic Geography, 1, 181-199.

Palpacuer, F., Seignour, A., \& Vercher, C. (2011). Financialization, globalization and the management of skilled employees. British Journal of Industrial Relations, 49(3), 560-582.

Pike, A., \& Pollard, J. S. (2010). Economic geographies of financialization. Journal of Economic Geography, 86, 29-51.

Pye, A. (2004). The importance of context and time for understanding board behavior: Some lessons from social capital research. International Studies of Management and Organization, 34(2), 63-89.

Roberts, J., Sanderson, P., Barker, R., \& Hendry, J. (2006). In the mirror of the market: The disciplinary effects of company/fund manager meetings. Accounting, Organizations and Society, 31, 227-294.

Ryan, L. V., \& Schneider, M. (2003). Institutional investor power and heterogeneity: Implications for agency and stakeholder theories. Business and Society, 42, 398-429.

Saramago, J. (2000). All the names. New York: Harcourt.

Shin, T. (2010). Mass layoffs and shareholder value orientation among large U.S. firms. Working paper. Urbana, Champaign: University of Illinois, Labor and Employment Relations Department.

Skaerbaek, P., \& Tryggestad, K. (2010). The role of accounting devices in performing corporate strategy. Accounting, Organizations and Society, $35,108-124$

Thompson, P. (2003). Disconnected capitalism: Or why employers can't keep their side of the bargain. Work Employment and Society, 17, 359-378. 
Thompson, P., \& Harley, B. (2013). Beneath the radar? A critical realist analysis of 'the knowledge economy' and 'shareholder value' as competing discourses. Organization Studies, 33(10), 1363-1381.

Thompson, P. (2013). Financialization and the workplace: extending and applying the disconnected capitalism thesis, Work. Employment and Society, 27, 472-488.

Vafeas, N., \& Shenoy, C. (2005). An empirical investigation of capital expenditure announcements. Applied Economics Letters, 12, 907-911.

Warhurst, C., \& Thompson, P. (2006). Mapping knowledge in work: Proxies or practices? Work Employment and Society, 20(4), 787-800.
Waring, M. (2013). All in this together? HRM and the individualisation of the academic worker. Higher Education Policy. http://dx.doi.org/ 10.1057/hep.2013.7.

Welch, J. (1981). Growing fast in a slow-growth economy. Speech delivered in Hotel Pierre, December 8th 1981. New York.

Williams, K. (2000). From shareholder value to present-day capitalism. Economy and Society, 29, 1-12.

Zorn, D., Dobbin, F., Dierkes, J., \& Kwok, M. S. (2005). Managing investors: How financial markets reshaped the American firm. In A. Preda \& K. Knorr Cetina (Eds.), The sociology of financial markets. New York: Oxford University Press. 